\begin{tabular}{l|l} 
Jurnal Eksplorasi Akuntansi & $\begin{array}{l}\text { Vol. 1, No 3, Seri F, Agustus 2019, Hal 1569-1588 } \\
\text { ISSN : 2656-3649 (Online) } \\
\text { http://jea.ppj.unp.ac.id/index.php/jea/issue/view/13 }\end{array}$
\end{tabular}

\title{
ANALISIS PENGARUH SANKSI ADMINISTRASI, TINGKAT PENDAPATAN, DAN SISTEM SAMSAT DRIVE THRU TERHADAP KEPATUHAN WAJIB PAJAK KENDARAAN BERMOTOR (Studi Kasus Kantor Samsat Kota Padang)
}

\author{
Prita Oktavianty Puteri ${ }^{1}$, Efrizal Syofyan ${ }^{2}$, Erly Mulyani ${ }^{3}$ \\ ${ }^{1)}$ Alumni Jurusan Akuntansi Fakultas Ekonomi, Universitas Negeri Padang \\ ${ }^{2,3)}$ Jurusan Akuntansi Fakultas Ekonomi, Universitas Negeri Padang \\ *Korespondensi: pritaoktavianty@gmail.com
}

\begin{abstract}
This study aims to find out empirical evidence whether there are effects of administrative sanctions, income levels, and SAMSAT drive thru on motor vehicle taxpayer compliance with empirical studies at the SAMSAT Office in Padang City. This research is a causative study. The population of this study is a motor vehicle taxpayer registered at the SAMSAT office in Padang City. The research sample was determined by slovin formula. The type of data used is subject data. The analytical method used is descriptive analysis and multiple regression analysis. The results of this study prove that there is a significant effect of administrative sanctions on motor vehicle taxpayer compliance, but the level of income and SAMSAT drive thru has no significant effect on motor vehicle taxpayer compliance.
\end{abstract}

Keywords: Administrative Sanctions, Income Level, SAMSAT Drive Thru, Taxpayer Compliance, Motor Vehicles

How to cite (APA $6^{\text {th }}$ style)

Puteri, P.O., Efrizal, S., Mulyani, M. (2019). Analisis Pengaruh Sanksi Administrasi, Tingkat Pendapatan, Dan Sistem Samsat Drive Thru Terhadap Kepatuhan Wajib Pajak Kendaraan Bermotor (Studi Kasus Kantor Samsat Kota Padang). Jurnal Eksplorasi Akuntansi, 1(3), Seri F, 1569-1588.

\section{PENDAHULUAN}

Pemerintah pada masa sekarang ini sedang giat untuk mewujudkan Indonesia yang maju dengan melakukan berbagai macam pembangunan. Dalam membiayai pembangunan dan menjalankanpsetiap program-program kerja pemerintah, dibutukan pemasukan yang diperoleh oleh negara. Sumber-sumber penerimaanpnegara berasal dari berbagai sektor yang salah satunya adalah sektor pajak.

Penerimaan negara dari sektor pajak dirasa mampu untuk menggali potensi pendapatan dari dalam negeri dikarenakan pajak merupakan sumber utama bagi penerimaan negara. Hasil dari pembayaran pajak digunakan untuk membiayai pengeluaran-pengeluaran negara dalam penyelenggaraan pemerintah yang bertujuan untuk meningkatkan kesejahteraan rakyat melalui pembangunan dan peningkatan sarana publik (Siahaan, 2013). 
Pajak memiliki sumbangsih besar dalam pembangunan negara ini. Sekitar $70 \%$ lebih sumber Anggaran Pendapatan Belanja dan Negara kita bersumber dari pajak. Oleh sebab itu segala macam potensi pajak dan penerimaan pajak harus digarap secara optimal oleh lembaga otoritas pajak yang mempuni. Melihat dariabperanan pajak yang sangat penting dalam memberikan kontribusi yang cukup besar bagi penerimaan negara maka pemungutan pajak harus dilaksanakan dengan semaksimal mungkin.

Dominasi pajak sebagai sumberppenerimaan negara merupakan suatu hal yang sangat wajar, sumber penerimaan ini mempunyai umur yang tidak terbatas, terlebih lagi dengan semakinlobertambahnya jumlah penduduk yang mengalami peningkatan setiap tahunnya. Pajak memiliki peran yang sangat besar dan semakin dapat diandalkankluntuk kepentingan pembangunan dan pengeluaran pemerintah (Hardiningsih, 2011)

Peranan penggunaan kendaraan bermotor dirasa mampu untuk meningkatkan penerimaan pajak kendaraan bermotor oleh pemerintah daerah, karena banyaknya jumlah penggunaan kendaraan bermotor yang digunakan masyarakat saat ini untuk memudahkan mobilitas masyarakat dalam bekerja dan beraktivitas. Tentunya hal ini dapat dimanfaatkan oleh pemerintah daerah dalam meningkatkan pendapatan asli daerah untuk melakukan pemungutan pajak kepada wajib pajak kendaraan bermotor.

Pemerintah daerah dapat mengoptimalkan penerimaan pajak kendaraan bermotor ini, tetapi dilihat dari data yang ada masih terdapat beberapa wajib pajak yang menunggak dalam pembayaran pajak kendaraan bermotornya. Ada banyak faktor yang menyebabkan teradinya kendala dalam penerimaan pajak kendaraan bermotor ini yaitu diantaranya kepatuhan dan kesadaran wajib pajak dalam melaksanakan tangunggungjawabnya dalam membayar pajak kendaraan bermotor.

\section{Tabel 1}

Data Jumlah Penerimaan Pajak Kendaraan Bermotor, Jumlah Tunggakan, dan Denda PKB di Kantor Bersama Samsat Kota Padang Tahun 2014-2018

\begin{tabular}{|c|c|c|c|c|c|c|}
\hline \multirow{2}{*}{ Tahun } & $\begin{array}{c}\text { Jumlah } \\
\text { Kendaraan }\end{array}$ & \multicolumn{2}{|c|}{ Jumlah penerimaan } & \multicolumn{2}{|c|}{ Tunggakan } & Denda \\
\cline { 2 - 7 } & (unit) & (unit) & $(\mathbf{R p )}$ & (unit) & (Rp) & (Rp) \\
\hline 2014 & 613.591 & 586.257 & 652.523 .481 .500 & 27.334 & 19.279 .412 .900 & 2.157 .051 .200 \\
\hline 2015 & 429.831 & 399.651 & 243.567 .433 .400 & 30.180 & 18.243 .651 .400 & 2.451 .782 .200 \\
\hline 2016 & 575.532 & 542.133 & 626.292 .412 .960 & 33.399 & 15.953 .188 .700 & 2.722 .459 .850 \\
\hline 2017 & 568.113 & 533.404 & 662.835 .182 .700 & 34.709 & 12.294 .472 .950 & 2.436 .354 .050 \\
\hline 2018 & 570.580 & 527.707 & 717.318 .077 .400 & 42.873 & 8.689 .997 .750 & 1.331 .109 .650 \\
\hline
\end{tabular}

Sumber : Badan Keuangan Daerah Provinsi Sumatera Barat

Menurut Menteri Keuangan dalam hal upayanpeningkatan penerimaan pajak, pemerintah akan meningkatkan efektivitasopenyuluhan dan hubungan masyarakat dalam rangka meningkatkan kesadaran dan kepatuhan wajib pajak. Misalnya denganklmelaksanakan reformasi pajak secara konsisten dan berkelanjutan, lalu meningkatkan pelayanan kepada wajib pajak dalam bentuk kemudahan pelaporan, pembayaran, dan kemudahan akses informasi.

Kepatuhan wajibppajak merupakan pemenuhan kewajiban perpajakan yang dilakukan oleh pembayar pajak dalam rangka memberikan kontribusi bagi pembangunanjkyang diharapkan dalam pemenuhannya diberikan secara sukarela. Kepatuhan wajib pajak dapatsdmenjadi salah satu penunjang yang mampu untuk meningkatkan pendapatan asli daerah sehingga pendapatan 
asli daerah yang diperoleh lebih optimal. Kesadaranbakan tanggung jawab ini menjadi yang fundamental dalam pembangunan dan diharapkan kepatuhan wajib pajak dapat diwujudkan.

Menurut Mariasmo (2009) menyatakanaisanksi perpajakan merupakan jaminan bahwa ketentuan peraturan perundang-undangan perpajakan (norma perpajakan) akan dituruti, ditaati, dan dipatuhi. Dengan demikian, diharapkan agar peraturan perpajakan dipatuhi olehppara wajib pajak. Penegakan hukum dalam perpajakan kendaraan bermotor diwujudkan dengan pemberian sanksi yaitu berupaklpengenaan sanksi administrasi pajak kendaraan bermotor kepada wajib pajak yang tidak melakukan pembayaran sesuai dengan tanggalkijatuh tempo yang ditetapkan. Sanksi Administrasi dalam perpajakan memiliki perankoyang penting guna memberikan efek jera kepada wajib pajak yang melakukan pelanggaran pajak. Pengenaan sanksi administrasi diberlakukankpuntuk menciptakan kepatuhan wajib pajak dalam melaksanakan kewajiban perpajakannya.

Terhambatnya penerimaanklpajak kendaraan bermotor secara optimal dipengaruhi juga oleh faktor tingkatan penghasilan wajib pajak. Faktor ekonomissmerupakan hal yang sangat fundamental dalam hal melaksanakan kewajiban perpajakan. Menurut Johanes (2011), ia menyatakan bahwa masyarakatkotidak akan menemui kesulitan dalam memenuhi kewajiban membayar pajaknya jika nilai yang harus dibayar masih dibawah penghasilan yang sebenarnya mereka peroleh secara rutin. Namun kesulitan untuk membayar pajakpakan dirasakan oleh masyarakat yang kurang mampu. Kebanyakan mereka cenderung memilih untruk memenuhi kebutuhan hidup terlebih dahulupsebelum membayar pajak. Oleh karena itu maka tingkat penghasilanpiseseorang dapat mempengaruhi kesadaran dan kepatuhan dalam melaksanakan ketentuan hukum dan kewajiban pajaknya.

Dalam upayapiuntuk mengoptimalkan tingkat kepatuhan wajib pajak kendaraan bermotor, pihak SAMSATpsebagai tempat pemungutan pajak kendaraan bermotor melakukan inovasi sistemyubaru pada pelayanan, karena salah satu tuntutan masyarakat kepada pemerintah adalah peningkatan pelayanan publik. Unit pelayananposamsat drive thru merupakan salah satu terobosan dalam upaya peningkatan mutu pelayanan. Masyarakat tidak akan kesulitan mengantri di depandiloket sehingga pajak kendaraan bermotor dapat diurus dengan cepat dan praktis. (Mawardi, 2011). Jika wajib pajak dalam melakukan pembayaran pajak kendaraan bermotor diberikanopkemudahan, kenyamanan, dan keamanan dari program-program samsat maka wajib pajak akan patuh dalam melaksanakan pembayaran pajak kendaraanpbermotor. Wajib pajak akan puas dengan kualitas pelayanan karena dapat menghemat waktu, serta dirasa cepat,tepat, efektif dan efisien dalam melakukan pembayaran pajakykendaraan bermotor (Wardani dan Rummiyatun, 2017).

Penelitian tentang sanksi administrasi juga dilakukan oleh Amalia, dkk (2018). Menurut Amalia, dkk kepatuhan wajib pajak bergantung pada kedua variabel yaitu variabel pengenaan sanksi administrasi dan kesadaran wajib pajak artinya pengenaan sanksi administrasi dan kesadaran wajib pajak berpengaruh nyata terhadap wajib pajak. Perbedaan penelitian ini dengan penelitian yang diteliti oleh Amalia, dkk (2018) adalah perbedaan variabel yang diteliti. Pada penelitian ini variabel yang digunakan adalah variable pengenaan sanksi administrasi, tingkatan pendapatan, dan sistem samsat drive thru terhadap kepatuhan wajib pajak kendaraan bermotor.

Dalam penelitian ini, peneliti mencoba mengangkat variable lainnya yaitu tingkatan pendapatan. Penelitian tentang pengaruh kualitas pelayanan, sanksi pajak, dan kondisi keuangan wajib pajak terhadap kepatuhan wajib pajak kendaraan bermotor ini sebelumnya telah dilakukan oleh Yanti (2018). Hasil penelitian menunjukan bahwa Kondisi keuangan wajib pajak kendaraan bermotor secara parsial memiliki pengaruh yang positif terhadap kepatuhan wajib pajak. Hal ini 
menunjukkan bahwa semakin baik kondisi keuangan wajib pajak maka makin baik pula kepatuhan wajib pajak.

Penelitian tentang kepatuhan wajib pajak kendaraan bermotor ini sebelumnya telah dilakukan oleh Wardani dan Fiktri (2018) pada kantor SAMSAT Daerah Istimewa Yogyakarta, dengan tujuan penelitian untuk menganalisis pengaruh program e-samsat terhadap kepatuhan wajib pajak. E-samsat merupakan sebuah program untuk meningkatkan kualitas pelayanan pembayaran pajak kendaraan bermotor dengan menggunakan alat elektronik seperti ATM. Hasil dari penelitian ini menunjukan bahwa program $e$-samsat berpengaruh positif terhadap kepatuhan wajib pajak kendaraan bermotor karena dinilai efektif dan efisien dalam memberikan kemudahan kepada wajib pajak kendaraan bermotor dalam melakukan pembayaran pajak. Perbedaan penelitian ini dengan penelitian yang dilakukan oleh Wardani dan Fikri (2018) adalah perbedaan pada jenis program yang digunakan oleh SAMSAT dalam meningkatkan kualitas pelayanannya. Dimana Wardani dan Fikri memakai variable $e$-samsat sementara pada penelitian ini menggunakan variable samsat drive thru.

Tujuan dari penelitian ini adalah untuk menganalisis pengaruh sanksi administrasi, tingkat pendapatan, dan sistem SAMSAT drive thru terhadap kepatuhan wajib pajak kendaraan bermotor dengan judul "Analisis Pengaruh Sanksi Administrasi, Tingkat Pendapatan, Dan Sistem Samsat Drive Thru Terhadap Kepatuhan Wajib Pajak Kendaraan Bermotor Di Kota Padang".

\section{REVIU LITERATUR DAN HIPOTESIS \\ Review Literatur \\ Teori Atribusi}

Teori atribusi menjelaskan bagaimana seseorang menyimpulkanpipenyebab dari tingkah laku yang dilakukan oleh dirii sendiri atau orang lain. Teoripini menjelaskan proses yang terjadi dalam diri seseorangmsehingga dapat memahami tingkah laku seseorang dani orang lain. Teori ini juga menjelaskan mengenai proses bagaimana seseorang menentukanbpenyebab dan motif tentang sikap dan perilakukseseorang. Teori ini mengacu tentang bagaimana seseorang menjelaskan penyebab perilaku orang lain atau dirinya sendiri yang akan ditentukan darippengaruh iinternal ataupun pengaruh eksternal yang akan memberikan dampak terhadapkperilaku individu..

Menurut Ayuningtyas (2012), teorii atribusi menjelaskan tentang pemahamanpbagaimana reaksi seseorang terhadap peristiwa yang dialami, dengan mengetahuilpenyebab atas kejadian yang dialami. Teori atribusi dijelaskan bahwa terdapat perilaku yang berhubungan dengan sikap danlkarakteristik individu,.maka dapat diartikan bahwanhanya denganlmelihat perilakunya maka akan dapat diketahui sikap ataupkarakteristik seseorang tersebut serta dapat juga memprediksioperilaku seseorang dalam menghadapi situasi tertentu.

\section{Compliance Theory (Teori Kepatuhan)}

Kepatuhanpberasal dari kata patuh. Menurut KamusoUmum Bahasa Indonesia, patuhiartinyaksuka dan taat kepada perintah atau aturan, dan berdisiplin. Kepatuhan berartipsifat patuh, taat, tunduk pada ajaran atau peraturan. Teori kepatuhanpi(compliance theory) merupakan teori yang menjelaskan suatu kondisi dimana seseorangotaat terhadap perintah atau aturan..yang diberikan. Kepatuhan wajib pajakrlmerupakan perilaku yang didasarkan pada kesadaran seorang wajib pajak terhadaplkewajiban perpajakannya dengan tetap berlandaskan..pada peraturan perundang-undangan yang telah ditetapkan. 
Teori kepatuhan dapat mendorong seseorang..untuk lebihpmematuhi peraturan yang berlaku, sama halnya dengan wajib pajak yang berusaha untukpmemenuhi kewajibannya yaitu membayar pajak secara tepat waktu. Pembayaran pajak yang dilakukan dengan tepat waktu akan dapatkmenguntungkan bagi..wajib pajak sendiri karena tidaklakan dikenakanwsanksi akibat keterlambatansmembayar pajak dan juga akan dapatomembantu negara didalam memenuhipikewajibannya yaitu untuk meningkatkan pembangunan infrastruktur mendukungkpelayanan publik.

\section{Pengertian Pajak}

Undang-Undang Nomor 28otahun 2007 tentangoketentuan Umum dan Tata Cara Perpajakan menyatakan bahwa pajak merupakan kontribusi wajib kepada negara yang terutang oleh orang pribadi atau badanlyang bersifatomemaksa berdasarkan Undang-Undang, dengan tidak mendapatkan imbalan secaraklangsung dan digunakan..untuk keperluan Negara bagi sebesarbesarnya kemakmurankrakyat.

Pajak adalahpiuran rakyat kepada kas negara berdasarkanpundang-undangl(yang dapat dipaksakan)kdenganktiadaamendapatsjasa timbale (kontraprestasi) yangklangsungkdapat ditunjukkankdantiyangidigun-akan untuk membayar pengeluaran umum. Sementara itu definisi pajak menurut Adriani, Pajakhadalahpiuran kepada..negaralyangkdapat dipaksakan yang. terhutang oleh yang wajib membayarnyakmenurut peraturan-peraturan, denganptidak mendapat prestasi kembali, yang langsung dapat ditunjuk, dan yangpgunanya adalah untuk membiayai pengeluaran-pengeluaran yang bersifatrrumumliberhubung dengan tugas Negarakuntuk menyelenggarakan pemerintahan

\section{Pajak Daerah}

Adalahrtpajak yang dipungutpoleh Pemerintah Daerahsbaik daerahttingkat I (pajak provinsi) maupunkdaerah tingkat II (pajak kabupaten/kota).dan digunakan untuktmembiayaitrumahntangga daerah masing-masing. Contohnya adalah Pajak Kendaraan Bermotor, Bea Balik Nama Kendaraan Bermotor, dan lain-lain. Menurut Mardiasmo (2011:12) pajak daerah adalah kontribusirtwajibpkepada daerah yang terutang oleh orang pribadi ataupbadan yang bersifat memaksa berdasarkan undang-undang, dengan tidakkmendapatkan imbalan secara langsungdan digunakan untuk.keperluan daerah bagijsebesar-besarnya kemakmuran rakyat.

\section{Pajak Kendaraan Bermotor}

Pajak Kendaraan Bermotorsiadalah atas kepemilikan dan/atau penguasaan atas kendaraan bermotor. Pajak ini dikenakan pada perorangan atau Badan yang memiliki dan/atau menguasai kendaraanabermotor. Menurut Zuraida (2011) objek pajak kendaraan bermotor adalah Kepemilikansdan/ataurtpenguasaan kendaraan bermotor. Subjeksrpajak kendaraan bermotor adalah orang pribadilatau badan yang memiliki atau menguasai kendaraan bermotor. Wajib pajak kendaraan,bermotor ialah orang pribadi ataukibadan yang memiliki kendaraan bermotor..

\section{Kepatuhan Wajib Pajak}

Kepatuhanbwajib pajak yaitu kepatuhan perpajakansyang sdiartikan sebagai suatuhkeadaan dimana wajibkpajak memenuhi semuakkewajiban perpajakan dandmelaksanakan hak perpajakannya. Adanya kepatuhan secara tidakjilangsung penerimaan pajak akan berjalan 
dengan lancar karena kepatuhan wajib pajak telah menunjukkan bahwa wajib pajak telah melaksanakankkewajiban perpajakan dengan baik (Haswidar,2016).

SedangkanrtmenurutiKeputusanrtMenterisKeuanganNo.544/kmk.04/2000r kepatuhan perpajakan ialah tindakan wajib pajak dalam pemenuhan kewajibanrtperpajakan sesuai dengan ketentuan peraturan perundang-undangan dan peraturan pelaksanaan perpajakan yang berlaku dalam suatusnegara. Jadi, dapat disimpulkan bahwa perilaku kepatuhan dalam membayar pajak sangat ditentukan oleh seberapa ketat pengawasan yang dilakukan oleh otoritas pajak. Semakin luas, efektif, dan tegas ruang lingkup pengawasan, maka muncul kecenderungan wajib pajak akan semakin patuh dalam membayar pajak.

\section{Kriteria Kepatuhan Wajib Pajak}

Menurutrpada kriteria wajib pajak patuh menurut Keputusan Menteri Keuangan No.544/kmk.04/2000 bahwa kriteria kepatuhan wajib pajak adalah:

a) Tepatgwaktu dalam menyampaikan SPT untuk semua jenis pajak dalam tahun terakhir.

b) Tidakfmempunyai tunggakan pajak untuk semua jenis pajak kecuali telah memperoleh izinkuntuk mengangsur atau menunda pembayaran pajak.

c) Tidakftpernah dijatuhi hukuman karena melakukanptindak pidana di bidang perpajakan dalam jangka waktu 10 tahun terakhir.

d) Dalamt2 tahun pajak terakhir, wajib pajak yang menyelenggarakan pembukuan dan pernah dilakukankkoreksi pada pemeriksaan yang terakhirjuntuk setiap jenis pajak yang terutang paling banyakk5\%.

e) Wajiblpajak yang laporkan keuangan untuk 2 tahun terakhir diaudit oleh akuntankpublik dengan pendapat wajar tanpa pengecualian atau dapatodengan pengecualian sepanjang tidakpmempengaruhi laba/rugi fiskal.

\section{Indikator Dalam Kepatuhan Wajib Pajak}

MenurutaWardani dan Asis (2017), adapun indikator yang dapat dijadikan ukuran dalam kepatuhan wajib pajak antara lain:

a) Memenuhi kewajiban pajak sesuai dengan ketentuan yang berlaku

b) Wajib pajak tidak mempunyai tunggakan pajak

c) Membayar pajak tepat waktunya

d) Wajib pajak memenuhi persyaratan dalam membayarkan pajaknya

e) Wajib pajak dapat mengetahui jatuh tempo pembayaran

a) Tidak pernah melanggar ketentuan peraturan

\section{Sanksi perpajakan}

Menurut Mardiasmo (2011) Sanksitrperpajakan merupakan jaminan bahwa ketentuan peraturan perundang-undanganopperpajakan (norma perpajakan) akan dipatuhi. Atau bisa dengan kata lainwsanksi perpajakan merupakan alat pencegah agar wajib pajak tidak melanggar norma.perpajakan. Sanksi pajakkterjadi karena pelanggaran terhadap peraturan perundangundangan perpajakan khususnya dalam ketentuan umum atau atau tata cara perpajakan (Resmi, 2009). Sehinggatapabila terjadi indikasi pelanggaran kebijakan perpajakan dan Undang-Undang Perpajakanrtmaka wajib pajak akan dihukum.

Sanksi adminstrasi perpajakan bertujuan untuk memberikan efek jera kepada wajib pajak sehingga tercipta kepatuhan wajib pajak dalam melaksanakan kewajiban perpajakannya Sanksi administrasi adalah suatu alat yang digunakanssebagai jaminantuntukkwajib pajak mematuhi 
semua peraturan perpajakan. Apabilalkwajib pajak melanggar ketentuan yang telah ditetapkan maka akanddikenai hukuman berupa bunga, denda dan kenaikan.

\section{Indikator Sanksi Perpajakan}

Indikator yang digunakan untuk mengukur variabeltsanksi perpajakan menurut Wardani \& Rummiyatun (2017):

a) Wajib pajak mengetahui dan paham mengenai tujuan sanksi pajak kendaraan bermotor

b) Pengenaantsanksi yang cukup berat merupakan salah satu untuk mendidik wajib pajak

c) Sanksi pajak harus dikenakan kepada wajib pajak yang melanggar tanpa toleransii

\section{Tingkat Pendapatan}

Faktorttekonomi merupakan hal yang sangatffundamental dalam hal ini melaksanakan kewajiban. Masyarakatpyang miskin akan menemukanjkesulitan untuk membayar pajak. Kebanyakanpmereka akan memenuhi kebutuhan hiduptterlebih dahulu sebelum membayar pajak. Karenanya, tingkattypendapatan seseorang dapat memengaruhi bagaimana seseorangptersebut memiliki kesadaran dan kepatuhan akan ketentuanshukum danikewajibannya (Haswidar, 2016).

Bloomqist dalam Yanti (2018) mengidentifikasi bahwa tekanan keuangan sebagai salah satu sumber tekanan bagi wajib pajak dan Bloomqist jugabberpendapat bahwa wajib pajak orangmpribadi yang mempunyai pendapatan yang terbatasmmungkin akan menghindari pembayarankpajak jika kondisiyikeuangan wajib pajak tersebut buruk karena pengeluaran keluarganya lebihmbesar dari pendapatannya. Menurut Ilham (2011) tingkat besarnya pendapatanvwajib pajak dapat mempengaruhi kepatuhan masyarakat dalam membayar pajak.

\section{Indikator Tingkatan Pendapatan}

Adapun indikator yang dapat dijadikan ukuran pada tingkatan pendapatan, antara lain:

a) Penghasilan yang diterima oleh wajib pajak (Haswidar, 2016)

b) Kesadaran wajib pajak untuk membayar pajak (Wardani \& Rummiyatun, 2017)

\section{Sistem SAMSAT Drive Thru}

SAMSAT drive thru adalah layanan yangmtransaksinyapdilakukan tanpa harus wajib pajakkturun dari kendaraannya, layanan tersebut berupa pengesahanmSTNK, PembayaranmPKB dan SWDKLLJ (Rohemah, 2013). Dalamihal inilwajib pajak tidak perlu turun dari kendaraannya. Wajib pajak cukup memberikanlSTNK lamanya besertatnominal pajak yang dikenakan diloket yang bisakdicapai. Selanjutnyapsetelahimelakukan transaksi, wajib pajakrttinggal mengambil buktikpembayaran pajak kendaraan dan tanda bukti perpanjangan STNK.

Keunggulan layananpdrive thru adalah dapat meminimalisirkcalo yang berkeliaran untuk mengambil keuntungan daripwajib pajak dan dalam pendataan kendaraan bermotor dapat lebih terkontrol. Layananodrive thru dibuat untukmmengefisienkan waktu para wajib pajak dalamjmembayarkan pajaknya tanpa haruskmengantri panjang. Transparansi pengelolaanlPajak Kendaraan Bermotor merupakan salah satu diadakannya inovasi ini (Bahari, 2013)

\section{Indikator Samsat Drive Thru}

Menurut Wardani dan Rumiyatun (2018) tentang layanan drive thru tersebut diukur dengan indikator sebagai berikut: 
1. Samsat drive thru dapat lebih terkontrol dalam hal pendataan kendaraan bermotor

2. Wajib pajak dapat dengan mudah membayar pajak dengan menggunakan samsat drive thru

3. Minat wajib pajak makin meningkat

4. Menghemat waktu

5. Kualitas pelayanan

6. Letak wilayah

\section{Penelitian Terdahulu}

Amalia, dkk (2018) melakukan penelitian tentang pengaruh pengenaan sanksi administrasi dan kesadaran wajib pajak terhadap tingkat kepatuhan wajib pajak kendaraan bermotor. Penelitian ini menggunakan sanksi administrasi dan kesadaran wajib pajak, sebagai variabel independen dan kepatuhan wajib pajak sebagai variabel dependen.

Haswidar (2016) melakukan penelitian yang bertujuan untuk mencari pengaruh tingkat pendapatan, pengetahuan dan kesadaran wajib pajak terhadap kepatuhan membayar pajak bumi dan bangunan. Penelitian itu dilakukan di Kecamatan Pammana, Kabupaten Wajo. Penelitian ini menggunakan tingkat pendapatan, pengetahuan dan kesadaran wajib pajak sebagai variabel independen sementara untuk variabel dependen yaitu kepatuhan wajib pajak. Berdasarkan hasil analisis yang dilakukan, penelitian Haswidar (2016) menunjukkan bahwa tingkat pendapatan tidak berpengaruh terhadap kepatuhan wajib pajak, tingkat pengetahuan dan kesadaran wajib pajak berpengaruh positif terhadap kepatuhan wajib pajak.

Penelitian tentang kepatuhan wajib pajak kendaraan bermotor ini sebelumnya telah dilakukan oleh Wardani dan Fiktri (2018), dengan tujuan penelitian untuk menganalisis pengaruh program e-samsat terhadap kepatuhan wajib pajak. Populasi dalam penelitian ini adalah semua wajib pajak kendaraan bermotor yang membayar kendaraannya melalui program $e$-samsat. Hasil dari penelitian ini menunjukan bahwa program $e$-samsat berpengaruh positif terhadap kepatuhan wajib pajak kendaraan bermotor karena dinilai efektif dan efisien dalam memberikan kemudahan kepada wajib pajak kendaraan bermotor dalam melakukan pembayaran pajak.

\section{Pengaruh Sanksi Administrasi Pajak Kendaraan Bermotor Terhadap Kepatuhan Wajib Pajak Kendaraan Bermotor}

Sanksi perpajakan adalah faktor lain yang dapat meningkatkan kepatuhan wajib pajakikendaraan bermotor (Isyatir, 2015). Pelaksanaan penegakanhhukum pajak secara tegas dan konsistenaakan mampu menciptakan kepatuhan yang lebih dari wajib pajak, yang bermuara pada peningkatanmpenerimaan dari sektor pajak.

Berdasarkan penelitian yang dilakukan oleh Amalia, dkk (2018) sejalan dengan penelitian Siamena, dkk (2017) yang mengatakan bahwa sanksi perpajakan berpengaruh positif pada kepatuhan wajib pajak dalam membayar Pajak Kendaraan Bermotor. Begitu juga dengan penelitian Ardiansyah (2018) yang mengatakan bahwa sanksi perpajakan berpengaruh positif pada kepatuhan wajib pajak dalam membayar Pajak Kendaraan Bermotor. Dari penjelasan tersebut maka dapat dirumuskan sebuah hipotesis sebagai berikut:

H1: Sanksi administrasi pajak kendaraan bermotor berpengaruh positif terhadap kepatuhan wajib pajak kendaraan bermotor

Pengaruh Tingkatan Pendapatan Terhadap Kepatuhan Wajib Pajak Kendaraan Bermotor Pendapatan merupakan tambahan kekayaan atau harta yang diperoleh dari dalam ataupun dari luar Negara yang dipungut untuk memenuhi kebutuhan hidupnya. Wajib pajak akan lebih 
memilih menggunakan pendapatannya untuk memenuhi kebutuhan hidupnya, dari pada menggunakan pendapatannya untuk membayar pajak.

Berdasarkan penelitian dari Ardiansyah (2018) menunjukkan bahwa tingkat penghasilan berpengaruh terhadap kepatuhan wajib pajak kendaraan bermotor. Hal ini juga didukung oleh penelitian Sari dan Susanti (2016) yang menyatakan tingkat penghasilan memiliki pengaruh yang besar terhadap kepatuhan wajib pajak dalam membayar Pajak Kendaraan Bermotor (PKB). Dari penjelasan tersebut maka dapat dirumuskan sebuah hipotesis sebagai berikut:

H2: Tingkatan pendapatan wajib pajak berpengaruh positif terhadap kepatuhan wajib pajak kendaraan bermotor

\section{Pengaruh Sistem SAMSAT Drive Thru Terhadap Kepatuhan Wajib Pajak Kendaraan Bermotor}

Program samsat drive thru adalah sebuah pelayanan dengan mempermudahssistem pelayanan kepada wajib pajak untuk melakukanmtransaksipotanpa harus turun dari kendaraan bermotor yang dikendarainya. Program samsat drive thru akanhberpengaruh positif terhadap kepatuhan wajib pajak apabila wajib pajak yang akan membayar pajak diberikankkualitas pelayanan yang baik, mudah, cepat dan aman dalam membayarppajak kendaraan bermotor.

Berdasarkan penelitian terdahulu yang dilakukan oleh Wardani dan Rumiyatun (2017) menunjukkan bahwa samsat drive thru berpengaruh positif terhadap kepatuhan wajib pajak kendaraan bermotor. Hal ini juga didukung oleh penelitian Rachmawati (2016) yang menunjukan bahwa pemungutan pajak melalui sistem SAMSAT drive thru sangat efektif. Penelitian Ardiansyah (2018) juga menyatakan bahwa SAMSAT drive thru berpengaruh positif terhadap kepatuhan wajib pajak kendaraan bermotor. Dari penjelasan tersebut maka dapat dirumuskan sebuah hipotesis sebagai berikut:

H3: Sistem samsat drive thru berpengaruh positif terhadap kepatuhan wajib pajak kendaraan bermotor

\section{Kerangka Konseptual}

Berdasarkan kerangka pemikiran dan teori - teori tersebut, maka penulis menyusun kerangka konseptual untuk penelitian sebagai berikut:

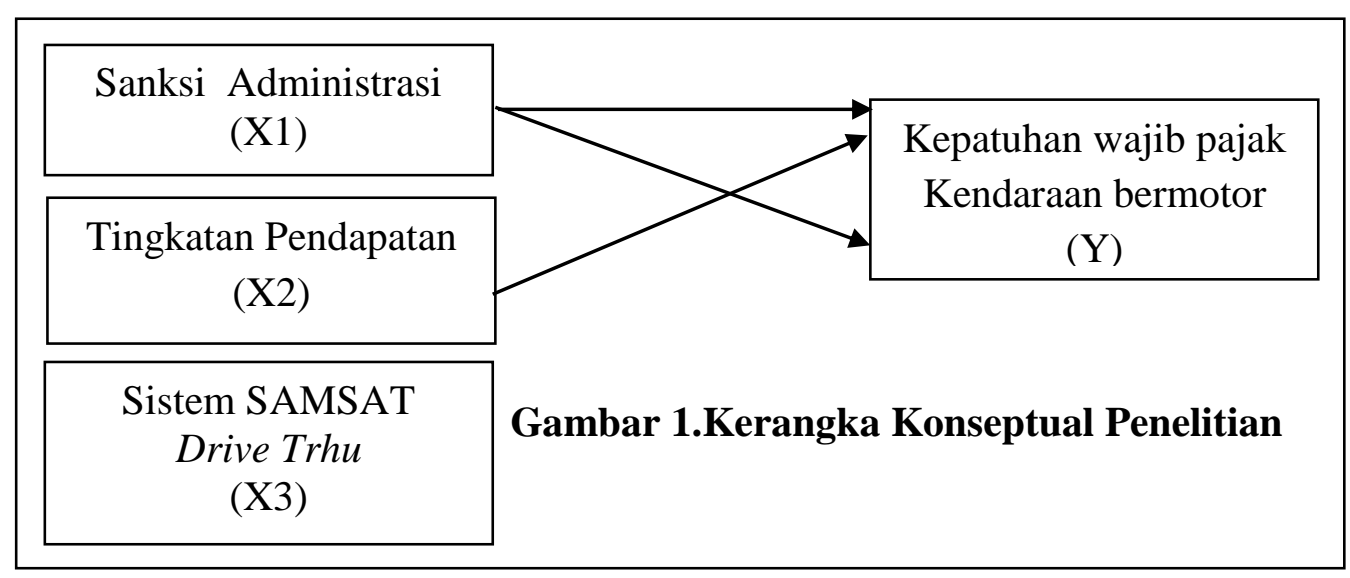




\section{METODE PENELITIAN}

Penelitian ini adalah penelitianokausatif. Penelitian ini merupakan tipe penelitian dengan karakteristik masalah berupaosebab-akibat antara dua variabel atau lebih. Jenis data yang digunakankdalam penelitian ini adalah data subjek, yaitu data yang berupa opini,psikap, pengalaman, dan karakteristik dari seseorangpoyang menjadi subjek penelitian ini. Dalam penelitian ini sumber data yangadiperoleh adalah data primer, yaitu data yang diperoleholangsung dari sampel yangktelah ditentukan untuk ditelitipatau melalui sumberkasli atau tanpa melalui perantara, dengan menggunakan metode surveygdengan menggunakan kuesioner. Penelitian ini diukur dengan menggunakan skalanlikert untuk mengukur sikap yang menyatakan setuju atau ketidaksetujuannya terhadap pertanyaan yang diajukan.

Dalam penelitian ini yang menjadi populasi adalah seluruh wajib pajak kendaraan bermotor yang kendaraannya terdaftar di kantor SAMSAT Kota Padang. Saat ini jumlah wajib pajak yang terdaftar di kantor samsat Kota Padang adalah sebanyak 58.447 unit kendaraan. Sedangkan samplenya diukur dengan menggunakan rumus slovin. Data yang digunakan oleh peneliti akan dianalisis dengan teknik analisispdeskriptif adalah proseskpengolahan data yang telah didapat daripresponden. Analisis kuantitatifyuadalah analisis yang berhubunganhdengan perhitunganmstatistik yangadidapatkan dengan mengolah data dari programsSPSS.

\section{Metode Analisis Data}

Penelitian ini menggunakancanalisis regresi berganda. Dalam hal menganalisis data agar dapat memberikan gambaran yang ringkas dan jelas mengenai mengenai variabel yang diteliti digunakan statistik deskriptif. Untuk menguji kualitas data digunakan uji validitas dan uji reliabilitas. Pengujian asumsi klasik dalam penelitian ini adalah adalah uji normalitas, uji heterokedasitas, dan uji multikolonearitas. Uji model meliputi uji koefisien determinasi, uji F, dan uji hipotesis

\section{HASIL DAN PEMBAHASAN \\ Gambaran Umum Objek Penelitian}

Populasi dalam penelitian ini adalah seluruh wajib pajak kendaraan bermotor yang kendaraannya terdaftar di kantor SAMSAT Kota Padang. Saat ini jumlah wajib pajak yang terdaftar di kantor SAMSAT Kota Padang adalah sebanyak 58.447 unit kendaraan. Sampel yang digunakan dalam penelitian ini adalah dengan menggunakan rumus slovin sebanyak 100 sampel.

\section{Demografi Responden}

Dari hasil penelitian yang telah dilakukan, dapat dilihat karakteristik dari seluruh responden yang menjadi sampel dalam penelitian ini, antara lain adalah karakteristik responden berdasarkan jenis kelamin, umur, tingkat pendidikan, dan jenis pekerjaan.

\section{Statistik Deskriptif}

Sebelum variabel penelitian dianalisis dengan pengujian rumus statistik, data dari masing-masing variabel penelitian dideskripsikan terlebih dahulu. Hal ini dimaksudkan agar dapat memberikan gambaran tentang masing-masing variabel yang diteliti. Data penelitian yang menjadi variabel dependen adalah Kepatuhan Wajib Pajak (Y), sedangkan yang menjadi variabel independen adalah Sanksi Administrasi(X1), Tingkat Pendapatan (X2), dan SAMSAT Drive Thru(X3). Hasil analisis deskriptif dengan menggunakan SPSS 16.0 dari variabel-variabel penelitian ini adalah sebagai berikut: 
Tabel 4.6

Descriptive Statistics

\begin{tabular}{|c|c|c|c|c|c|c|c|c|}
\hline & $\mathrm{N}$ & Range & Minimum & Maximum & Sum & \multicolumn{2}{|c|}{ Mean } & $\begin{array}{c}\text { Std. } \\
\text { Deviation }\end{array}$ \\
\hline & Statistic & Statistic & Statistic & Statistic & Statistic & Statistic & $\begin{array}{l}\text { Std. } \\
\text { Error }\end{array}$ & Statistic \\
\hline Sanksi Administrasi & 97 & 15 & 20 & 35 & 2967 & 30.59 & .352 & 3.463 \\
\hline Tingkatan Pendapatan & 97 & 8 & 12 & 20 & 1575 & 16.24 & .230 & 2.267 \\
\hline $\begin{array}{l}\text { Sistem SAMSAT Drive } \\
\text { Thru }\end{array}$ & 97 & 26 & 39 & 65 & 5540 & 57.11 & .653 & 6.427 \\
\hline $\begin{array}{l}\text { Kepatuhan Wajib Pajak } \\
\text { Kendaraan Bermotor }\end{array}$ & 97 & 24 & 41 & 65 & 5471 & 56.40 & .580 & 5.715 \\
\hline Valid N (listwise) & 97 & & & & & & & \\
\hline
\end{tabular}

Sumber: Data Primer yang Diolah, 2019

Berdasarkan tabel diatas, dijelaskan bahwa variabel sanksi administrasi memiliki nilai rata-rata sebesar 30,59 dengan deviasi standar 3,463, nilai tertinggi 35, dan nilai terendah 20. Variabel tingkat pendapatan memiliki nilai rata-rata sebesar 21,02 dengan deviasi standar 2,402, nilai tertinggi 25 dan nilai terendah 16. Variabel SAMSAT drive thru memiliki nilai rata-rata sebesar 57,11 dengan deviasi standar 6,427, nilai tertinggi 65 dan nilai terendah 39. Sedangkan untuk variabel kepatuhan wajib pajak kendaraan bermotor memiliki nilai rata-rata sebesar 56,40 dengan deviasi standar 5,715, nilai tertinggi 65 dan nilai terendah 41

\section{Uji Instrumen}

\section{Uji Validitas}

Berdasarkan perhitungan nilai Corrected Item-Total Colleration yang diperoleh, menunjukkan hasil bahwa nilai terkecil Corrected Item-Total Colleration dari masing-masing item variabel $\mathrm{X}_{1}$, $\mathrm{X}_{2}, \mathrm{X}_{3}$, dan $\mathrm{Y}$ berada diatas $\mathrm{r}_{\text {tabel. }}$. Oleh karena $\mathrm{r}_{\text {hitung }}>\mathrm{r}_{\text {tabel }}$ maka butir pertanyaan tersebut dapat dikatakan valid. Jadi dapat disimpulkan bahwa seluruh item variabel $\mathrm{X}_{1}, \mathrm{X}_{2}, \mathrm{X}_{3}$, dan $\mathrm{Y}$ adalah valid.

\section{Uji Reliabilitas}

Dari perhitungan yang dilakukan diperoleh nilai Cronbach's Alpha masing-masing item variabel menunjukkan tingkat koefisien keandalan untuk kepatuhan wajib pajak 0,842, untuk sanksi administrasi 0,776, untuk tingkatan pendapatan 0,692, dan untuk sistem SAMSAT drive thru 0,930. Nilai Cronbach's Alpha seluruh item variabel tersebut menunjukkan nilai diatas 0,6. Oleh karena nilai Cronbach's Alpha > 0,60 variabel yang digunakan dalam penelitian ini dapat dikatakan bahwa seluruh instrumen penelitian baik dan reliabel.

\section{Uji Asumsi Klasik}

\section{Uji Normalitas}

Uji normalitas dilakukan dengan metode kolmogorov smirnov, dengan melihat nilai signifikansi pada 0,05 . Jika nilai signifikansi yang dihasilkan >0,05 maka data berdistribusi normal. 
Tabel 4.12

Tabel Uji Normalitas

One-Sample Kolmogorov-Smirnov Test

\begin{tabular}{|c|c|c|c|c|c|c|}
\hline & & $\begin{array}{c}\text { Sanksi } \\
\text { Administrasi }\end{array}$ & $\begin{array}{l}\text { Tingkatan } \\
\text { Pendapatan }\end{array}$ & $\begin{array}{l}\text { SAMSAT } \\
\text { Drive Thru }\end{array}$ & $\begin{array}{l}\text { Kepatuhan } \\
\text { Wajib Pajak }\end{array}$ & $\begin{array}{l}\text { Unstandardiz } \\
\text { ed Residual }\end{array}$ \\
\hline \multicolumn{2}{|l|}{$\mathrm{N}$} & 97 & 97 & 97 & 97 & 97 \\
\hline \multirow{2}{*}{$\begin{array}{l}\text { Normal } \\
\text { Parameters }\end{array}$} & Mean & 30.59 & 21.02 & 57.11 & 56.40 & .0000000 \\
\hline & $\begin{array}{l}\text { Std. } \\
\text { Deviation }\end{array}$ & 3.463 & 2.402 & 6.427 & 5.715 & 4.18045728 \\
\hline \multirow{3}{*}{$\begin{array}{l}\text { Most Extreme } \\
\text { Differences }\end{array}$} & Absolute & .143 & .095 & .137 & .115 & .117 \\
\hline & Positive & .102 & .094 & .110 & .095 & .057 \\
\hline & Negative & -.143 & -.095 & -.137 & -.115 & -.117 \\
\hline \multicolumn{2}{|c|}{ Kolmogorov-Smirnov Z } & 1.407 & .931 & 1.352 & 1.130 & 1.148 \\
\hline \multicolumn{2}{|c|}{ Asymp. Sig. (2-tailed) } & .038 & .352 & .052 & .156 & .143 \\
\hline
\end{tabular}

Sumber : Data Primer yang Diolah, 2019

Berdasarkan tabel 4.12 diatas, terlihat dari uji normalitas yang dilakukan menghasilkan perhitungan Kolmogorov-Smirnov sebesar 0,551 dengan nilai signifikansi sebesar 0,143. Berdasarkan perhitungan diatas, nilai signifikansi $0,143>0,05$, sehingga dapat dikatakan data yang digunakan dalam penelitian ini berdistribusi normal.

\section{Uji Multikolinearitas}

Uji multikolonearitas bertujuan untuk menguji apakah model regresi yang ditemukan terdapat kolerasi antar variabel bebas.Untuk mengujinya, dilakukan dengan melihat nilai Variance Inflantions Factor (VIF). Jika nilai VIF $<10$ dan tolerance $>0,1$, maka variabel dapat dikatakan bebas multikolonearitas.

Tabel 4.13

Tabel Uji Moltikolinearitas

Coefficients $^{\mathrm{a}}$

\begin{tabular}{|c|c|c|c|c|c|c|c|c|}
\hline & & \multicolumn{2}{|c|}{$\begin{array}{l}\text { Unstandardized } \\
\text { Coefficients }\end{array}$} & \multirow{2}{*}{$\begin{array}{c}\text { Standardized } \\
\text { Coefficients } \\
\text { Beta } \\
\end{array}$} & \multirow[b]{2}{*}{$\mathrm{t}$} & \multirow[b]{2}{*}{ Sig. } & \multicolumn{2}{|c|}{$\begin{array}{l}\text { Collinearity } \\
\text { Statistics }\end{array}$} \\
\hline \multicolumn{2}{|c|}{ Model } & B & Std. Error & & & & $\begin{array}{c}\text { Toleranc } \\
\mathrm{e}\end{array}$ & VIF \\
\hline 1 & (Constant) & 19.559 & 5.074 & & 3.855 & .000 & & \\
\hline & $\begin{array}{l}\text { sanksi administrasi } \\
\text { (X1) }\end{array}$ & 1.026 & .148 & .622 & 6.914 & .000 & .711 & 1.406 \\
\hline & $\begin{array}{l}\text { tingkatan } \\
\text { pendapatan (X2) }\end{array}$ & .313 & .202 & .132 & 1.546 & .125 & .796 & 1.257 \\
\hline & $\begin{array}{l}\text { samsat drive thru } \\
(\mathrm{X} 3)\end{array}$ & -.020 & .074 & -.022 & -.265 & .791 & .833 & 1.201 \\
\hline
\end{tabular}

Sumber : Data Primer yang Diolah, 2019

Berdasarkan hasil uji multikolinearitas pada tabel 4.13 diatas, diperoleh nilai tolerance untuk variabel sanksi administrasi sebesar 0,711, variabel tingkatan pendapatan sebesar 0,796 dan variabel SAMSAT drive thru sebesar 0,833. Sedangkan nilai VIF variabel sanksi administrasi sebesar 1,406, variabel tingkatan pendapatan sebesar 1,257, dan variabel SAMSAT 
drive thru sebesar 1,201. Dari nilai tolerance dan VIF seluruh variabel tersebut, didapatkan bahwa seluruh variabel independen memiliki nilai tolerance $>0,10$ serta memiliki nilai VIF < 10. Dengan demikian, dapat dikatakan bahwa tidak ditemukan korelasi variabel-variabel bebas antara satu dengan yang lainnya, atau dapat disimpulkan tidak terjadi multikolinearitas.

\section{Uji Heteroskedastisitas}

Uji heterokedastisitas bertujuan untuk menguji apakah dalam model regresi terjadi ketidaksamaan varian dari residual satu pengamatan ke residual satu pengamatan yang lain. Pengujian ini menggunakan uji Glejser. Apabila Sig > 0,05, maka tidak terdapat gejala heterokedastisitas.

Tabel 4.14

\section{Uji Heterokedastisitas}

Coefficients $^{\mathrm{a}}$

\begin{tabular}{|c|c|c|c|c|c|c|}
\hline \multirow{2}{*}{\multicolumn{2}{|c|}{ Model }} & \multicolumn{2}{|c|}{ Unstandardized Coefficients } & \multirow{2}{*}{$\begin{array}{c}\begin{array}{c}\text { Standardized } \\
\text { Coefficients }\end{array} \\
\text { Beta }\end{array}$} & \multirow[b]{2}{*}{$\mathrm{t}$} & \multirow[b]{2}{*}{ Sig. } \\
\hline & & $\mathrm{B}$ & Std. Error & & & \\
\hline \multirow[t]{4}{*}{1} & (Constant) & -.828 & 3.161 & & -.262 & .794 \\
\hline & Sanksi & -.026 & .092 & -.034 & -.278 & .782 \\
\hline & Pendapatan & .225 & .126 & .204 & 1.787 & .077 \\
\hline & SAMSAT & .002 & .046 & .004 & .034 & .973 \\
\hline
\end{tabular}

Sumber : Data Primer yang Diolah, 2019

Berdasarkan hasil uji heterokedastisitas yang terdapat pada tabel 4.14 diatas, didapatkan nilai signifikansi dari variabel sanksi administrasi sebesar 0,794, nilai signifikansi variabel pendapatan sebesar 0,07, dan nilai signifikansi untuk variabel SAMSAT drive thru sebesar 0,973. Dari hasil tersebut, diketahui bahwa seluruh variabel dalam penelitian ini memiliki nilai signifikansi > 0,05, yang berarti dalam model regresi ini dapat dikatakan bahwa tidak ada variabel yang signifikan dengan variabel absut. Dengan demikian dapat disimpulkan model yang digunakan dalam penelitian ini terbebas dari heterokedastisitas.

\section{Model Regresi Berganda}

Model regresi berganda dilakukan untuk menyatakan hubungan fungsional variabel bebas dan variabel terikat. Analisis regresi berganda dilakukan dengan menggunakan pengolahan dari program SPSS 16. 
Tabel 4.15

Uji Regresi Berganda

Coefficients $^{\mathrm{a}}$

\begin{tabular}{|c|c|c|c|c|c|}
\hline \multirow[b]{2}{*}{ Model } & \multicolumn{2}{|c|}{ Unstandardized Coefficients } & \multirow{2}{*}{$\begin{array}{c}\text { Standardized } \\
\text { Coefficients } \\
\text { Beta }\end{array}$} & \multirow[b]{2}{*}{$t$} & \multirow[b]{2}{*}{ Sig. } \\
\hline & $B$ & Std. Error & & & \\
\hline (Constant) & 19.559 & 5.074 & & 3.855 & .000 \\
\hline Sanksi Administrasi & 1.026 & .148 & .622 & 6.914 & .000 \\
\hline Tingkatan Pendapatan & .313 & .202 & .132 & 1.546 & .125 \\
\hline SAMSAT Drive Thru & -.020 & .074 & -.022 & -.265 & .791 \\
\hline
\end{tabular}

a. Dependent Variable: Kepatuhan Wajib Pajak

Sumber : Data Primer yang Diolah, 2019

Angka yang dihasilkan dalam persamaan regresi berganda tersebut dapat dijelaskan sebagai berikut :

\section{Konstanta ( $\alpha)$}

Nilai konstanta sebesar 19,559 yang berarti bahwa jika variabel independen yaitu sanksi administrasi, tingkatan pendapatan, dan SAMSAT drive thru adalah 0, maka nilai kepatuhan wajib pajak kendaraan bermotor berada pada 19,559 satuan.

\section{Koefisien Regresi $\boldsymbol{\beta}_{1} \mathbf{X}_{1}$}

Koefisien sanksi administrasi sebesar 1,026 yang mengindikasikan bahwa setiap peningkatan sanksi administrasi satu satuan akan mengakibatkan peningkatan kepatuhan wajib pajak kendaraan bermotor sebesar 1,026 satuan. Nilai koefisien $\beta$ dari variabel $X_{1}$ bernilai positif yaitu 1,026 .

\section{Koefisien Regresi $\boldsymbol{\beta}_{2} \mathbf{X}_{2}$}

Koefisien tingkatan pendapatan sebesar 0,313 yang mengindikasikan bahwa setiap peningkatan tingkatan pendapatan satu satuan akan mengakibatkan peningkatan kepatuhan wajib pajak kendaraan bermotor sebesar 0,313 satuan. Nilai koefisien $\beta$ dari variabel $X_{2}$ bernilai positif yaitu 0,452 .

\section{Koefisien Regresi $\boldsymbol{\beta}_{3} \mathbf{X}_{3}$}

Koefisien SAMSAT drive thru sebesar $-0,020$ mengindikasikan bahwa setiap peningkatan SAMSAT drive thru satu satuan akan mengakibatkan penurunan kepatuhan wajib pajak kendaraan bermotor sebesar $-0,020$ satuan. Nilai koefisien $\beta$ dari variabel $\mathrm{X}_{3}$ bernilai negatif, yaitu -0,257. Hal ini mengandung makna bahwa SAMSAT drive thru berpengaruh negatif terhadap kepatuhan wajib pajak kendaraan bermotor.

\section{Uji Model}

\section{Uji Koefisien Determinasi}

Menurut Ghozali (2007), koefisien determinasi $\left(\mathrm{R}^{2}\right)$ mengukur seberapa jauh kemampuan model dalam menerangkan variabel dependen. Nilai koefisien determinasi adalah antara nol dan satu. Nilai koefisien determinasi dilakukan dengan melihat nilai Adjust $R$ Square. Nilai Adjust 
RSquare yang kecil berarti kemampuan variabel independen dalam menjelaskan varian variabel dependen amat terbatas.

\section{Tabel 4.16}

Uji Koefisien Determinasi

Model Summary

\begin{tabular}{|l|r|r|r|r|}
\hline Model & $\mathrm{R}$ & $\mathrm{R}$ Square & \multicolumn{1}{|c|}{$\begin{array}{c}\text { Adjusted R } \\
\text { Square }\end{array}$} & $\begin{array}{c}\text { Std. Error of the } \\
\text { Estimate }\end{array}$ \\
\hline 1 & $.682^{\mathrm{a}}$ & .465 & .448 & 4.247 \\
\hline
\end{tabular}

a. Predictors: (Constant), SAMSAT Drive Thru, Tingkatan

Pendapatan, Sanksi Administrasi

Sumber : Data Primer yang Diolah, 2019

Berdasarkan hasil uji koefisien determinasi pada tabel 4.16 diatas, diketahui bahwa nilai Adjust $R$ Square adalah sebesar 0,448 atau sama dengan 44,8\%. Hal ini menjelaskan bahwa variabel sanksi administrasi, tingkatan pendapatan, sistem SAMSAT drive thru memiliki kontribusi dalam menerangkan variabel dependen yaitu sebesar 44,8\%. Sedangkan sisanya yaitu sebesar 55.2\% dipengaruhi oleh variabel lain yang tidak terdeteksi dalam penelitian ini.

\section{Uji F}

Uji F dilakukan untuk menguji apakah secara serentak variabel independen mampu menjelaskan variabel dependen secara baik atau untuk menguji apakah model yang digunakan telah pasti atau tidak.Pengujian dilakukan dengan melihat nilai sig. $0,00<0,05$ dan membandingkan $F_{\text {hitung }}$ dengan $\mathrm{F}_{\text {tabel}}$, yang berarti menunjukkan bahwa variabel independen secara bersama - sama memberikan pengaruh yang signifikan terhadap variabel dependen. $F_{\text {tabel }}$ untuk $\mathrm{df}=52$ pada level signifikansi 0,05 adalah 4,03.

\begin{tabular}{|c|c|c|c|c|c|}
\hline & & Tal & $\begin{array}{l}\text { el } 4.17 \\
\text { Ji F }\end{array}$ & & \\
\hline Model & Sum of Squares & Df & Mean Square & $\mathrm{F}$ & Sig. \\
\hline Regression & 1457.602 & 3 & 485.867 & 26.933 & $.000^{\mathrm{a}}$ \\
\hline Residual & 1677.717 & 93 & 18.040 & & \\
\hline Total & 3135.320 & 96 & & & \\
\hline
\end{tabular}

a. Predictors: (Constant), SAMSAT Drive Thru, Tingkatan Pendapatan, Sanksi Administrasi

b. Dependent Variable: Kepatuhan Wajib Pajak

\section{Sumber : Data Primer yang Diolah, 2019}

Berdasarkan uji $\mathrm{F}$ pada tabel 4.17 diatas, menunjukkan nilai $\mathrm{F}_{\text {hitung }}$ sebesar 26,933 dan signifikan pada nilai signifikan 0,000. Nilai $F_{\text {hitung }}>F_{\text {tabel }}$ yaitu 26,933>42,70, dan nilai signifikansi $0,000<0,05$, maka dapat dipastikan bahwa model regresi dalam penelitian ini dapat digunakan dalam memprediksi pengaruh variabel independen terhadap variabel dependen dalam penelitian ini. Dengan demikian, dapat disimpulkan bahwa sanksi administrasi, tingkatan pendapatan,dan SAMSAT drive thru secara bersama-sama atau secara simultan berpengaruh signifikan terhadap kepatuhan wajib pajak kendaraan bermotor. 


\section{Uji Hipotesis}

Pengujian ini dilakukan untuk mengetahui masing-masing variabel bebas terhadap variabel terikat secara parsial atau individual. Uji t dilakukan dengan membandingkan $t_{\text {hitung }}$ dengan $t_{\text {tabel }}$ pada taraf signifikan $\alpha=0,05$ dengan derajat kebebasan $(\mathrm{dk})=\mathrm{n}-\mathrm{k}-1=97-3-1=93$ adalah 1,989. Berdasarkan hasil uji regresi berganda untuk uji hipotesis pada tabel 4.15, maka dapat dilihat pengaruh antar variabel independen terhadap variabel dependen secara parsial sebagai berikut :

\section{Pengujian Hipotesis 1}

Nilai $t$ hitung untuk variabel sanksi administrasi $\left(\mathrm{X}_{1}\right)$ adalah 6,914 dan nilai signifikan 0,001. Sehingga dapat diketahui bahwa $\mathrm{t}_{\text {hitung }}>\mathrm{t}$ tabel yakni 6,914>1,989 dan nilai signifikansi $0,000<$ 0,05 . Nilai koefisien $\beta$ dari variabel $X_{1}$ bernilai positif yaitu 1,026 . Hal ini menunjukkan dan membuktikan bahwa variabel sanksi administrasi $\left(\mathrm{X}_{1}\right)$ berpengaruh positif dan signifikan terhadap kepatuhan wajib pajak, sehingga hipotesis pertama diterima.

\section{Pengujian Hipotesis 2}

Nilai thitung untuk variabel tingkatan pendapatan $\left(\mathrm{X}_{2}\right)$ adalah 1,546 dan nilai signifikan 0,125. Sehingga dapat diketahui bahwa $\mathrm{t}_{\text {hitung }}<\mathrm{t}$ tabel yakni 1,546 $<1,989$ dan nilai signifikansi 0,125 > 0,05 . Nilai koefisien $\beta$ dari variabel $\mathrm{X}_{2}$ bernilai positif yaitu 0,313 . Hal ini menunjukkan dan membuktikan bahwa variabel tingkat pendapatan $\left(\mathrm{X}_{2}\right)$ berpengaruh tidak signifikan terhadap kepatuhan wajib pajak kendaraan bermotor, sehingga hipotesis kedua ditolak.

\section{Pengujian Hipotesis 3}

Nilai thitung untuk variabel SAMSAT drive thru $\left(\mathrm{X}_{3}\right)$ adalah $-0,265$ dan nilai signifikan 0,791 . Sehingga dapat diketahui bahwa $\mathrm{t}_{\text {hitung }}<\mathrm{t}_{\text {tabel }}$ yakni $-0,265<1,989$ dan nilai signifikansi 0,791 $>0,05$. Nilai koefisien $\beta$ dari variabel $X_{3}$ bernilai negatif yaitu $-0,020$. Dengan demikian hal ini menunjukkan dan membuktikan bahwa variabel pengalaman kerja $\left(\mathrm{X}_{3}\right)$ berpengaruh negatif dan tidak signifikan terhadap kepatuhan wajib pajak kendaraan bermotor, sehingga hipotesis ketiga ditolak.

\section{PEMBAHASAN}

\section{Pengaruh Sanksi Administrasi Terhadap Kepatuhan Wajib Pajak Kendaraan Bermotor}

Berdasarkan hasil pengujian hipotesis dengan menggunakan model regresi linier berganda menunjukkan bahwa sanksi administrasi berpengaruh positif dan signifikan terhadap kepatuhan wajib pajak kendaraan bermotor. Hal ini ditunjukan dengan nilai signifikansi $0,000<0,05$. Hasil penelitian ini sejalan dengan hasil penelitian yang dilakukan oleh Amalia, dkk (2018) serta Siamena, dkk (2017) yang menjelaskan bahwa sanksi administrasi berpengaruh positif dan signifikan terhadap kepatuhan wajib pajak kendaraan bermotor. Begitu juga dengan penelitian Ardiansyah (2018) mengatakan bahwa sanksi perpajakan berpengaruh positif pada kepatuhan wajib pajak dalam membayar Pajak Kendaraan Bermotor.

Sanksi pajak kendaraan bermotor sangat diperlukan dalam upaya penegakkan hukum untuk mewujudkan ketertiban wajib pajak dalam membayar pajaknya. Sanksi pajak memiliki peran penting guna memberikan pelajaran bagi pelanggar pajak agar tidak meremehkan peraturan perpajakan (Ardiansyah, 2018). Secara logika jika sanksi pajak semakin baik dan tertib dilaksanakan maka kepatuhan pajak seseorang dalam membayar pajak juga akan meningkat. Adanya ketegasan sanksi yang berlaku, menyebabkan masyarakat lebih tertib baik untuk 
menghindari sanksi administrasi perpajakan. Masyarakat juga menyadari bahwa mereka merasa keberatan adanya sanksi yang diberikan apabila melanggar tidak membayar pajak. Dengan adanya sanksi yang ditetapkan oleh Pemerintah ini, maka wajib pajak akan bersikap patuh untuk menghindari sanksi pajak jika melakukan pelanggaran.

\section{Pengaruh Tingkat Pendapatan Terhadap Kepatuhan Wajib Pajak Kendaraan Bermotor}

Berdasarkan hasil pengujian hipotesis dengan menggunakan model regresi linier berganda menunjukkan bahwa tingkat penghasilan tidak berpengaruh signifikan terhadap kepatuhan wajib pajak kendaraan bermotor. Hal ini ditunjukan dengan nilai signifikansi 0,125>0,05. Hasil penelitian ini sejalan dengan hasil penelitian yang dilakukan oleh Haswidar (2016) dan Isawati (2016) yang menjelaskan bahwa tingkat pendapatan berpengaruh tidak berpengaruh signifikan terhadap kepatuhan wajib pajak kendaraan bermotor. Begitu juga dengan penelitian Rahman (2017) mengatakan bahwa tingkat pendapatan berpengaruh tidak signifikan pada kepatuhan wajib pajak dalam membayar Pajak Kendaraan Bermotor.

Besar kecilnya pendapatan yang diterima oleh wajib pajak berpengaruh tetapi tidak signifikan terhadap kepatuhan wajib pajak dalam membayar pajak kendaraan bermotor. Wajib pajak yang berpenghasilan tinggi belum tentu patuh dalam membayar pajak begitu juga sebaliknya wajib pajak yang berpenghasilan rendah belum tentu tidak patuh dalam membayar pajak.

\section{Pengaruh SAMSAT Drive Thru terhadap Kepatuhan Wajib Pajak Kendaraan Bermotor}

Berdasarkan hasil pengujian hipotesis dengan menggunakan model regresi linier berganda menunjukkan bahwa samsat drive thru berpengaruh negatif dan tidak signifikan terhadap kepatuhan wajib pajak kendaraan bermotor. Hasil ini dibuktikan dengan nilai signifikansi 0,791 $>0,05$. Hasil ini sekaligus tidak sejalan dengan penelitian yang dilakukan oleh Wardani dan Rumiyatun (2017) dan Ardiyansyah (2018) yang menyatakan bahwa SAMSAT drive thru berpengaruh signifikan positif terhadap kepatuhan wajib pajak kendaraan bermotor.

Tidak berpengaruhnya variabel SAMSAT drive thru dalam penelitian ini disebabkan oleh beberapa hal, salah satunya disebabkan oleh letak lokasi SAMSAT drive thru yang kurang strategis sehingga wajib pajak masih merasa kesulitan dalam membayar pajak kendaraan bermotor miliknya. Hal ini juga disebabkan oleh terdapatnya beberapa pilihan lain dalam membayar pajak kendaraan beromotor sehingga lebih memudahkan wajib pajak dalam membayar pajak kendaraan miliknya.

\section{KESIMPULAN DAN SARAN}

\section{Kesimpulan}

Berdasarkan hasil analisis data dan pengujian hipotesis yang telah dilakukan, maka dapat ditarik kesimpulan sebagai berikut :

1. Sanksi administrasi berpengaruh signifikan positif terhadap kepatuhan wajib pajak kendaraan bermotor.

2. Tingkatan pendapatan berpengaruh tidak signifikan terhadap kepatuhan wajib pajak kendaraan bermotor.

3. SAMSAT drive thru berpengaruh negatif dan tidak signifikan terhadap kepatuhan wajib pajak kendaraan bermotor. 


\section{Saran}

Berdasarkan analisis data dan hasil yang diperoleh dalam penelitian ini, terdapat beberapa saran yang dapat dipertimbangkan antara lain :

1. Dalam rangka meminimalisir wajib pajak yang terkena sanksi administrasi karena masih banyaknya wajib pajak yang terlambat membayar pajak, maka pihak SAMSAT sebagai lembaga pemungut pajak perlu lebih mensosialisasikan pentingnya membayar pajak sesuai dengan tanggal jatuh tempo pembayaran. Sosialisasi ini dapat membantu meningkatkan kesadaran wajib pajak melalui penyuluhan tentang manfaat pajak, tata cara pembayaran pajak kendaraan bermotor yang mudah dipahami sehingga dapat meningkatkan upaya kepatuhan wajib pajak kendaraan bermotor.

2. Dalam hal tingkatan pendapatan, diharapkan kepada wajib pajak agar membayar pajak dengan dorongan hati nurani, memahami pentingnya pajak bagi pembangunan daerah, melaksanakan kewajiban perpajakan sesuai dengan kebijakan perpajakan.

3. Layanan SAMSAT drive thru tetaplah harus menjadi program dalam mempertimbangkan peningkatan kepatuhan wajib pajak kendaraan bermotor, walaupun dalam penelitian ini SAMSAT drive thru berpengaruh negatif dan tidak siginifikan terhadap kepatuhan wajib pajak. Namun ada baiknya jika sosialisasi terhadap penggunaan SAMSAT drive thru yang dapat memberikan kemudahan kepada wajib pajak kendaraan bermotor lebih disosialisasikan secara terus menerus sehingga dapat menghasilkan kepatuhan wajib pajak yang lebih baik.

\section{DAFTAR PUSTAKA}

Adi, Titis Wahyu. (2018). Pengaruh Pengetahuan Perpajakan, Sanksi Pajak Dan Kesadaran Wajib Pajak Terhadap Kepatuhan Wajib Pajak Badan Pada KPP Pratama Cilacap TahunY2018. Skripsi. Yogyakarta: Universitas Negeri Yogyakarta

Adiputra, I Putu Eka dan Dewa Gede Wirama. (2017). Pengaruh Kualitas Pelayanan, Sanksi Perpajakan Dan Kesadaran Wajib Pajak Pada Kepatuhan Wajib Pajak. Jurnal. Bali: Universitas Udayana

Affandi, Ahmad. (2008). Efektifitas Pelayanan Publik oleh Kantor Bersama SAMSAT Mojokerto melalui SamsatYLink. Malang: Universitas Brawijaya

Andreas, Damianus. (2017). "Delapan Strategi Menkeu Tingkatkan Penerimaan Pajak", https://tirto.id/delapan-strategi-menkeu-tingkatkan-penerimaan-pajak-csXZ.

Amalia, dkk. (2018). Pengaruh Pengenaan Sanksi Administrasi Dan Kesadaran Wajib Pajak Terhadap Tingkat Kepatuhan Wajib Pajak Kendaraan Bermotor (Studi Kasus Pada Kantor Samsat Bengkalis Riau). Malang: Universitas Brawijaya

Ayuningtyas, Harvita Y.(2012). Pengaruh Pengalaman Kerja, Independensi, Objektivitas, Integritas, dan Kompetensi Terhadap Kualitas Hasil Audit (Studi Kasus Pada Auditor Inspektorat Kota/Kabupaten di Jawa Tengah). Skripsi. Semarang:Universitas Diponegoro.

Direktorat Jenderal Pajak, Undang-undang Nomor 28 Tahun 2007 tentang Perubahan Ketiga atas Undang-undang Nomor 6 tahun 1983 tentang Ketentuan Umum dan Tata Cara Perpajakanm

Direktorat Jenderal Pajak, Undang-undang nomor 28 Tahun 2009 tentang Pajak Daerah dan Retribusi Daerah 
Ernawati. 2014. Pengaruh Tingkat Pendidikan, Pendapatan, dan Kualitas Pelayanan Fiskus terhadap Kepatuhan Wajib Pajak. Skripsi. Fakultas Ekonomi dan Bisnis Universitas Hasanuddin.

Ghozali, Imam. 2007. Aplikasi Analisis Multivarite Dengan SPSS. Semarang: Universitas Diponegoro.

Hardiningsih, P dan N. Yulianawati. (2011). Faktor-faktor yang mempengaruhi kemauan membayar pajak. Jurnal Dinamika Keuangan dan Perbankan. Universitas Stikubank

Haswidar. (2016). Pengaruh Tingkat Pendapatan, Pengetahuan, Dan Kesadaran Wajib Pajak Terhadap Kepatuhan Membayar Pajak Bumi Dan Bangunan Di Kecamatan Pammana Kabupaten Wajo. Skripsi. Makassar: Universitas Hasanudin

Jatmiko, Agus Nugroho.(2006). Pegaruh Sikap Wajib Pajak pada Sanksi Denda, Pelayanan Fiskus, dan Kesadaran Perajakan terhadap kepatuhan Wajib Pajak Orang Pribadi di kota Semarang. Tesis Program Pasca Sarjana Magister Sains Ilmu Akuntansi. Journal. Universitas Dipenegoro.

Johanes, Hengki. (2011). Faktor-Faktor Yang Mempengaruhi Kemauan Membayar Pajak Bumi Dan Bangunan $(\mathrm{Pbb})$ Di Kecamatan Brebes Kabupaten Brebes. Tegal. Universitas Pancasakti.

Koentarto, Ilham. (2011). Analisis Faktor Faktor Yang Mempengaruhi Kepatuhan Masyarakat Dalam Melakukan Pembayaran Pajak Bumi dan Bangunanb(Studi Kasus Pada Kecamatan Arut Selatan Kabupaten Kota Waringin Barat). Jurnal. Universitas Antakusuma

Lestari, Nur Wachida Cinitya. (2016). Faktor -Faktor Yang Memengaruhi Kepatuhan Wajib Pajak Dalam Membayar Pajak Kendaraan Bermotor (Studi Kasus Samsat Kabupaten Kepulauan Selayar). Universitas Hasanudin

Mardiasmo. 2009. Perpajakan. Edisi Revisi 2009. Yogyakarta, Penerbit Andi.

Mawardi, Leganek. (2011). Optimalisasi Samsat Drive Thru Guna Mewujudkan Pelayanan Prima Dalam Rangka Mendukung Transparansi Pelayanan Polri Pada Kantor Bersama Samsat Jakara Selatan. Skripsi. Universitas Indonesia, Jakarta

Masruroh, Siti dan Zulaikha. (2013). Pengaruh Kemanfaaatan NPWP, Pemahaman Wajib Pajak, Kualitas Pelayanan, Sanksi Perpajakan Terhadap Kepatuhan Wajib Pajak (Studi Empiris Pada WPOP Di Kabupaten Tegal). Journal. Universitas Diponegoro

Nugroho, Seno Adi. (2017). Indikator keberhasilan DJP adalah Tingkat Kepatuhan Wajib Pajak. Badan Pendidikan dan Pelatihan Keuangan Kementerian Keuangan. ( www.bppk.kemenkeu.go.id)

Peraturan Daerah Nomor 6 Tahun 2010 tentang Ketentuan Umum Pajak Daerah diakses 4 April 2019 (23.06)

Prianggono, Jarot dan Adrian, Heru. (2010). Pengaruh Kualitas Pelayanan Samsat Drive Thru terhadap Kepuasan Masyarakat di Polda Metro Jaya. Jurnal Kajian Komunikasi, Bahasa dan Budaya

Rahman, Arif. (2018). Pengaruh Kesadaran Wajib Pajak, Tingkat Pendidikan Dan Pendapatan terhadap Kepatuhan Membayar Pajak Bumi Dan Bangunan. Jurnal. Padang:Universitas Negeri Padang.

Resmi, Siti. 2014. Perpajakan Teori dan Kasus. Salemba Empat. Jakarta

Rohemah, Riskiyatur, dkk. 2013. Analisis Pengaruh Implementasi Layanan SAMSAT Keliling Terhadap Kepatuhan Wajib Pajak Kendaraan Bermotor Roda Dua Di Kabupaten Pamekasan. Jurnal. Universitas Trunojoyo 
Siahaan, Mariot P. 2013. Pajak Daerah dan Retribusi Daerah, Jakarta : Raja Grafindo Suandy, Erly. (2011). Hukum Pajak, Edisi 5, Jakarta: Salemba Empat

Sugiyono. (2017). Metode Penelitian Kuantitatif, Kualitatif, dan R\&D. Bandung : Alfabeta

Tahar, dan Rachman. 2014. Pengaruh Faktor Internal dan Faktor Eksternal Terhadap Kepatuhan Wajib Pajak. Jurnal Akuntansi dan Investasi. Yogyakarta: Universitas Negeri Yogyakarta.

www.unpad.ac.id. Studium Generale dan Diskusi Panel Road Map Strategi Perpajakan yang Amanah dan Berkeadilan Untuk Kesejahteraan Masyarakat Indonesia. 6 Maret 2019 (21.36)

Waluyo. (2009). Akuntansi Pajak. Jakarta . Penerbit : Salemba Empat

Wardani, Dewi Kusuma dan Fikri Juliansya. (2018). Pengaruh Program E-Samsat Terhadap Kepatuhan Wajib Pajak Kendaraan Bermotor Dengan Kepuasan Kualitas Pelayanan Sebagai Variabel Intervening ( Studi Kasus SAMSAT Daerah Istimewa Yogyakarta. Jurnal. Universitas Sarjanawiyata Tamansiswa.

Wardani, Dewi Kusuma dan Rumiyatun. (2017). Pengaruh Pengetahuan Wajib Pajak, Kesadaran Wajib Pajak, Sanksi Pajak Kendaraan Bermotor, dan Sistem SAMSAT Drive Thru Terhadap Kepatuhan Wajib Pajak Kendaraan Bermotor. Yogyakarta. Jurnal. Universitas Sarjanawiyata Tamansiswa

Wardani, Dewi Kusuma dan Moh Rifqi Asis (2017). Pengaruh Pengetahuan Pajak dan Program Samsat Corner Terhadap Kepatuhan Wajib Pajak Kendaraan Bermotor

Yanti, Widia Dwi Ratna. (2018). Pengaruh kualitas pelayanan, sanksi pajak, dan kondisi keuangan terhadap kepatuhan wajib pajak kendaraan bermotor. Surabaya. Jurnal. Universitas Negeri Surabaya

Zuraida, Ida. 2012. Teknik Penyusunan Peraturan Daerah. Jakarta: Sinar Grafika. 